\title{
A phase 1 study evaluating the pharmacokinetics, safety and tolerability of repeat dosing with a human IL-13 antibody (CAT-354) in subjects with asthma
}

Dave Singh ${ }^{1}$, Binita Kane ${ }^{1}$, Nestor A Molfino ${ }^{2 *}$, Raffaella Faggioni ${ }^{2}$, Lorin Roskos ${ }^{2}$, Ashley Woodcock ${ }^{1}$

\begin{abstract}
Background: IL-13 has been implicated in the development of airway inflammation and hyperresponsiveness. This study investigated the multiple-dose pharmacokinetics and safety profile of human anti-IL-13 antibody (CAT-354) in adults with asthma.

Methods: This was a multiple-dose, randomised, double-blind, placebo-controlled phase 1 study in asthmatics (forced expiratory volume in 1 second $\left[\mathrm{FEV}_{1}\right] \geq 80 \%$ predicted). Subjects were randomised to receive three intravenous infusions of CAT-354 (1 mg/kg, $5 \mathrm{mg} / \mathrm{kg}$ or $10 \mathrm{mg} / \mathrm{kg}$ ) or placebo at 28-day intervals. Blood samples were taken for pharmacokinetic measurements. Safety was assessed by adverse events, vital signs, ECGs, laboratory and pulmonary function parameters.

Results: Twenty-three subjects (aged 21-60 years, FEV $188-95 \%$ predicted) received $\geq 1$ dose of study medication. The half-life of CAT-354 was 12-17 days and was dose-independent. The maximum serum concentration and area under the curve were dose-dependent. Clearance $(2.2-2.6 \mathrm{~mL} /$ day $/ \mathrm{kg})$ and volume of distribution $(44-57 \mathrm{~mL} / \mathrm{kg})$ were both low and dose-independent. The observed maximum serum concentration after each dose increased slightly from dose 1 through dose 3 at all dose levels, consistent with an accumulation ratio of 1.4 to 1.7 for area under the curve. Most adverse events were deemed mild to moderate and unrelated to study medication. One SAE was reported and deemed unrelated to study drug. There were no effects of clinical concern for vital signs, ECG, laboratory or pulmonary parameters.
\end{abstract}

Conclusions: CAT-354 exhibited linear pharmacokinetics and an acceptable safety profile. These findings suggest that at the doses tested, CAT-354 can be safely administered in multiple doses to patients with asthma.

Trial registration: NCT00974675.

\section{Background}

Asthma is characterised by variable airflow obstruction and airway hyperresponsiveness (AHR) in association with airway inflammation [1]. Inhaled corticosteroids (ICS) are currently the first-line anti-inflammatory treatment for persistent asthma [1]. However, many asthma patients remain symptomatic despite ICS therapy $[2,3]$. Alternative anti-inflammatory therapies are needed in asthma.

\footnotetext{
* Correspondence: molfinon@medimmune.com

${ }^{2}$ Respiratory and Inflammation, MedImmune LLC, Gaithersburg, Maryland,
} USA

T helper-2 (TH-2) lymphocytes release cytokines, including IL-4, IL-5 and IL-13, that have a range of actions, including eosinophil activation and immunoglobulin secretion from B cells. Clinical studies have shown that asthma is associated with TH-2 inflammation [4-6]. Targeting the cytokines involved in TH-2 inflammation may therefore be an effective therapeutic strategy.

IL-13 levels are increased in the airways of patients with asthma $[7,8]$. Of particular importance is the finding that IL-13 positive cells are present within the airway smooth muscle and expressed predominantly by mast cells, suggesting that IL-13 plays a pivotal role in 
mast cell-airway smooth muscle interactions [9]. The genes encoding for IL-13 and IL-4 are both located on the cytokine cluster on chromosome $5 \mathrm{q} 31$. These TH-2 cytokines share some structural similarities, and both exert their actions through the IL-4R $\alpha / \mathrm{IL}-13 R \alpha 1$ receptor complex; therefore, these cytokines have overlapping functions. IL-4 also exerts independent effects through the IL-4R $\alpha / \gamma$ receptor. However, animal models suggest a dominant role for IL-13 in the pathophysiology of allergic inflammation, as IL-13 causes AHR, eosinophilic inflammation and mucus hypersecretion [10-14]. Antagonising the function of IL-13 in asthma may be a therapeutically effective strategy.

CAT-354 is a high affinity, human monoclonal IgG4 antibody that specifically binds to and neutralises IL-13. This study aimed to assess the pharmacokinetics, tolerability and safety of repeated doses of CAT-354 in subjects with mild to moderate asthma.

\section{Methods}

\section{Subject eligibility}

This study was conducted at two UK sites: the Medicines Evaluation Unit and the Chiltern clinical research unit. Ethics approval was obtained at both sites and the study was conducted in accordance with ICH Good Clinical Practice guidelines and in compliance with the 2000 Declaration of Helsinki. All subjects provided written informed consent prior to the performance of any study-specific procedures.

Subjects aged 18 to 60 years with a physician diagnosis of asthma were eligible to participate in this study. Female subjects were either postmenopausal (no menstrual period for a minimum of 1 year) or surgically sterilised. Subjects had to have a forced expiratory volume in 1 second $\left(\mathrm{FEV}_{1}\right)$ of $\geq 80 \%$ of predicted normal and be well controlled on ICS and short-acting $\beta_{2}$ agonists (SABA) only with no change in the dose of ICS for 3 months prior to the study. Subjects were also required to not have smoked in the previous year and have a smoking history of $\leq 10$ pack years.

Exclusion criteria were an asthma exacerbation requiring hospitalisation within 3 years of the study, a history of any active disease other than eczema, seasonal allergy which was expected to start before the last dose of study material, poorly controlled asthma defined as SABA $>6$ times/day on any one day or $>3$ times/day on six or more days within the 2 weeks prior to the study, previous treatment with any other asthma medications within 6 months of the study, treatment for atopic symptoms except eczema within the previous 4 weeks, any acute illness in the prior 2 weeks, a lower respiratory tract infection within 4 weeks, previous treatment with a monoclonal antibody or related protein and participation in another study within 3 months (or
5 half-lives of the investigational product). Participants had to have a medical history negative for alcohol or substance abuse and no clinically significant ECG or clinical chemistry, haematology or urinalysis result.

\section{Study design}

The study was a double-blind, randomised, placebo-controlled phase 1 study. Subjects attended the clinic for 13 visits over a 147-day study period (Figure 1). Subjects had a screening visit up to 28 days prior to randomisation. Study eligibility was confirmed at the randomisation visit, at which subjects were randomised to receive CAT-354 or placebo in addition to their usual medication (ICS and SABA). Subjects were recruited sequentially to one of three dose groups and randomised within each dose group to receive either CAT-354 $(1 \mathrm{mg} / \mathrm{kg}, 5 \mathrm{mg} / \mathrm{kg}$ or $10 \mathrm{mg} / \mathrm{kg}$ ) or placebo. Within each group, randomisation to CAT-354 or placebo was in a ratio of 4:1, respectively. CAT-354 was formulated at a nominal concentration of $10 \mathrm{mg} / \mathrm{mL}$ in phosphatebuffered saline (MedImmune). The placebo solution, phosphate-buffered saline, was supplied in matching vials. Study treatment was administered by 30 -minute intravenous infusion at each of these visits using a syringe pump. Each subject received three doses of the assigned treatment, administered with a 28 -day interval between doses. As a safety precaution, the first 3 subjects within each dose group were administered CAT354 with at least 24 hours between subjects. Follow up for pharmacokinetic blood sampling and safety observations continued up to day 147 after the first dose (91 days after the third dose).

\section{Study procedures}

\section{Pharmacokinetic assessments}

Serum samples for pharmacokinetic assessments were obtained pre-dose and at 10 minutes and 12 hours after the infusion on dosing days. Single samples were also collected at all other visits. Serum concentrations of CAT-354 and anti-CAT-354 were assessed by MedImmune using a quantitative sandwich ELISA based immunoassay performed on the Gyrolab assay platform. This method exhibits accuracy of $\leq 25 \%$ absolute relative error and precision of $\leq 20 \%$ coefficient of variation with a lower limit of quantification of $0.300 \mu \mathrm{g} / \mathrm{mL}$.

\section{Safety assessments}

Safety was assessed by monitoring the occurrence of adverse events or abnormalities identified by standard laboratory tests, vital sign measurements, physical examinations and ECGs. Laboratory tests were performed at screening and 7 days after administration of each dose and the end of the study. Samples for urinalysis were collected at screening and the end of the study only, as were physical examinations. Vital signs were taken at screening and on dosing days pre-dose and prior to discharge after each dose and at the end of the study. 


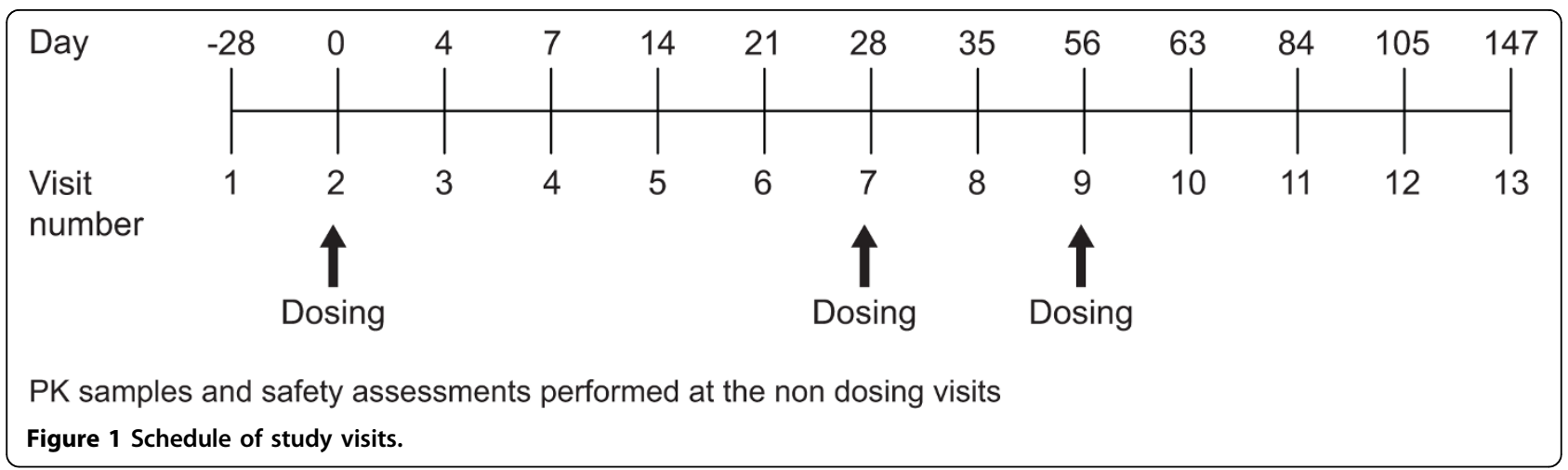

ECGs were performed at the screening visit, within 6-7 hours after the first dose and at the end of the study.

\section{Immunogenicity evaluations}

To assess any immunogenic response, blood samples of all subjects taken pre-dose and at the last clinic visit were tested for the presence of anti-CAT-354 antibodies using a double-bridging ELISA assay [15] with a sensitivity of $1 \mu \mathrm{g} / \mathrm{mL}$ for the detection of an anti-idiotypic monoclonal antibody standard against CAT-354. Immuno-inhibition by CAT-354 and an isotype matched control antibody as an additional confirmatory assay was performed to eliminate false positive results.

\section{Lung function assessments}

$\mathrm{FEV}_{1}$, forced vital capacity (FVC) and the $\mathrm{FEV}_{1} / \mathrm{FVC}$ ratio were measured using a standardised, calibrated spirometer at each visit. At dosing visits, lung function was measured pre-dose and 30 minutes and 12 hours after the infusion. Wherever possible, pulmonary function tests were recorded at the same time of day.

\section{Statistical analysis}

It was planned that eight subjects per dose group were to be evaluated for CAT-354. In addition, it was planned that a minimal number of subjects (6 in total) were to be allocated to placebo as a control for the assessment of tolerability (giving an overall ratio of 4:1 active:control). Cohorts of this size are considered to be adequate to provide the information required to fulfill the objectives of the study whilst exposing a minimum number of subjects to investigational product [16].

All safety and tolerability assessments were based on the safety population, defined as all subjects who received at least one dose of study material. No formal statistical testing was performed on safety data due to the exploratory nature of the study. The pharmacokinetic population was defined as all subjects in the safety population for whom sufficient post-dose blood samples were taken to estimate the observed maximum concentration $\left(C_{\max }\right)$ and was used for pharmacokinetic parameter estimates. The pharmacokinetic parameters were estimated for each subject using WinNonlin software
(Pharsight Corporation, California, version 5). Non-compartmental analysis was performed to generate parameter estimates using model 202 (intravenous infusion). The elimination phase volume of distribution $(\mathrm{Vd})$ was calculated from clearance and the elimination rate constant.

\section{Results}

\section{Demographics and baseline characteristics}

Due to the slow recruitment rate, the study was closed before the planned number of subjects was achieved in the highest dose group $(10 \mathrm{mg} / \mathrm{kg})$. A total of $23 \mathrm{sub}-$ jects ( 22 male, 1 female) were randomised and included in the safety population. An additional 23 subjects were screened but were not eligible for the study (Figure 2). Of the 23 subjects included in the safety population, 19 subjects were also included in the pharmacokinetic population. Four subjects received placebo and were therefore not included in the pharmacokinetic population. Baseline characteristics of the safety population are shown in Table 1. All subjects had at least a 1-year history of asthma and were using ICS (mean overall beclomethasone dipropionate dose, $400 \mu \mathrm{g} /$ day; range, 100$1000 \mu \mathrm{g} /$ day) and SABA only.

\section{Pharmacokinetics}

Of the 19 subjects in the pharmacokinetic population, 5 did not complete the study and receive all three doses of CAT-354 (Figure 2). The full range of pharmacokinetic parameters could therefore only be derived for the 14 subjects who received all three doses. The serum concentration-time profiles for each dosing group are shown in Figure 3.

After a single dose, the half-life was 12-17 days and independent of dose level. Serum concentrations were still well above the limit of quantification by 28 days, when the next dose was given. Serum concentrations for the second and third doses generally increased at all time points.

Dose proportional increases in $\mathrm{C}_{\max }, \mathrm{AUC}_{(0-\mathrm{t})}$ and $\mathrm{AUC}_{(0 \text {-inf) }}$ were observed after a single dose (Table 2). 


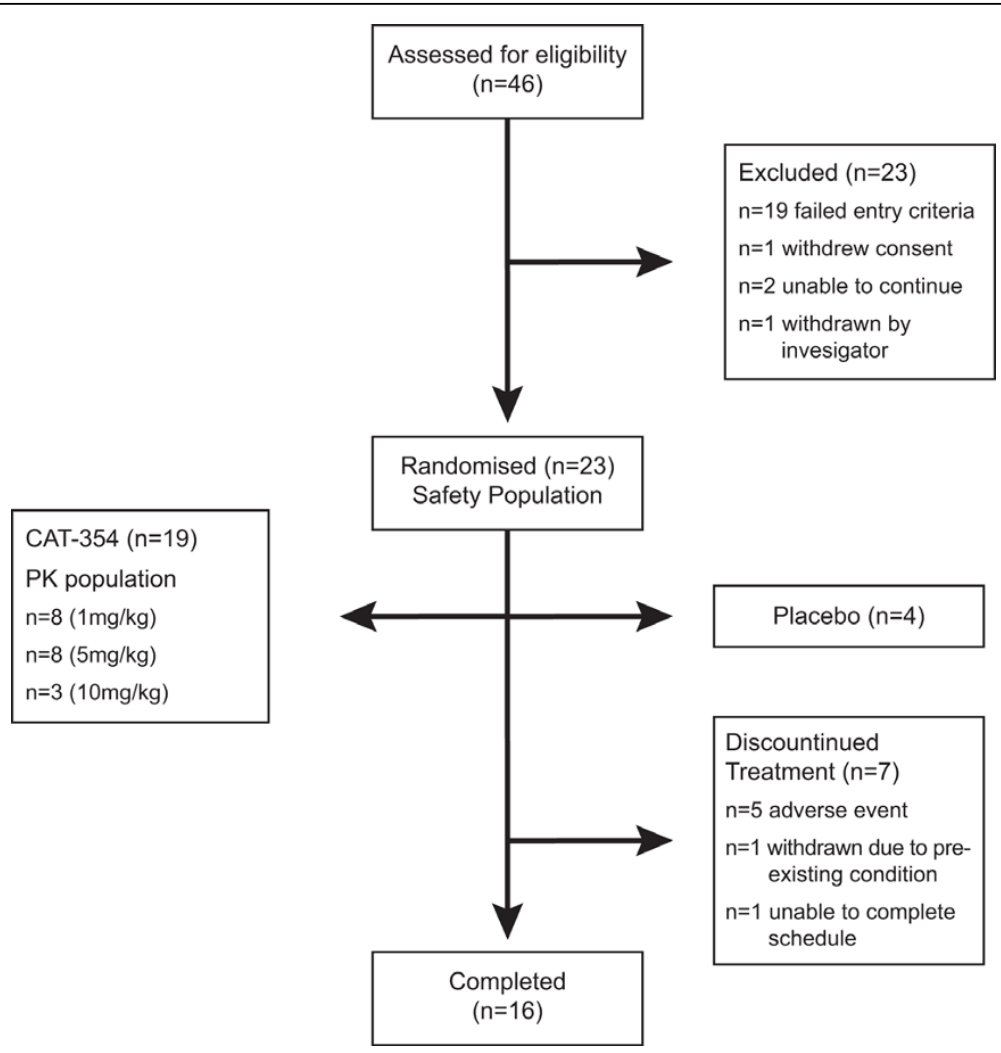

Figure 2 Flowchart of subjects through the study.

Table 1 Baseline characteristics of the safety population

\begin{tabular}{|c|c|c|c|c|}
\hline & & Anti-IL-13 & & \\
\hline & $1 \mathrm{mg} / \mathrm{kg}(\mathrm{n}=8)$ & $5 \mathrm{mg} / \mathrm{kg}(\mathrm{n}=8)$ & $10 \mathrm{mg} / \mathrm{kg}(\mathrm{n}=3)$ & Placebo $(n=4)$ \\
\hline Randomised, n & 8 & 8 & 3 & 4 \\
\hline Completed study, n (\%) & $6(75.0)$ & $7(87.5)$ & $1(33.3)$ & $2(50.0)$ \\
\hline \multicolumn{5}{|l|}{ Sex, n (\%) } \\
\hline Male & $8(100)$ & $8(100)$ & $2(66.6)$ & $4(100)$ \\
\hline Female & 0 & 0 & $1(33.3)$ & 0 \\
\hline \multicolumn{5}{|l|}{ Age, years } \\
\hline Mean (SD) & $39.4(9.1)$ & $34.6(7.6)$ & $43.3(14.5)$ & $40.0(13.0)$ \\
\hline Range & $26-54$ & $21-46$ & $34-60$ & $26-53$ \\
\hline \multicolumn{5}{|l|}{ Race, n (\%) } \\
\hline White & $8(100)$ & $7(87.5)$ & $3(100)$ & $4(100)$ \\
\hline Black & 0 & $1(12.5)$ & 0 & 0 \\
\hline \multicolumn{5}{|l|}{ Weight, kg } \\
\hline Mean (SD) & $78.5(11.2)$ & $88.3(17.3)$ & $78.3(20.7)$ & $76.0(9.8)$ \\
\hline \multicolumn{5}{|l|}{$\mathrm{BMI}, \mathrm{kg} / \mathrm{m}^{2}$} \\
\hline Mean (SD) & $24.6(3.0)$ & $26.3(4.3)$ & $27.3(3.1)$ & $23(3.0)$ \\
\hline \multicolumn{5}{|l|}{$\%$ predicted $\mathrm{FEV}_{1}$} \\
\hline Mean (SD) & $95.3(8.3)$ & $95.5(9.8)$ & $90.7(9.5)$ & $88.8(4.6)$ \\
\hline \multicolumn{5}{|l|}{$\mathrm{FEV}_{1}$} \\
\hline Mean (SD) & $3.83(0.54)$ & $4.17(0.54)$ & $3.01(1.35)$ & $3.64(0.68)$ \\
\hline \multicolumn{5}{|l|}{ ICS dose, $\mu \mathrm{g} / \mathrm{d}$} \\
\hline Median (range) & $400(200-400)$ & $400(200-1000)$ & $200(200-480)$ & \\
\hline
\end{tabular}




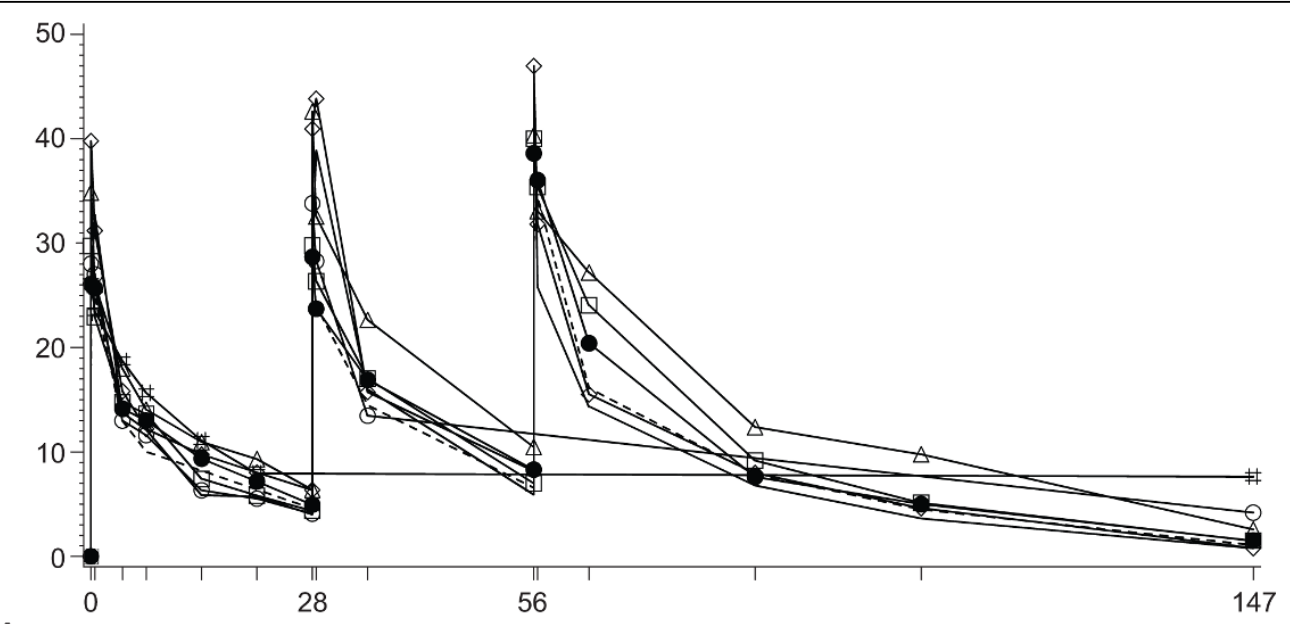

A
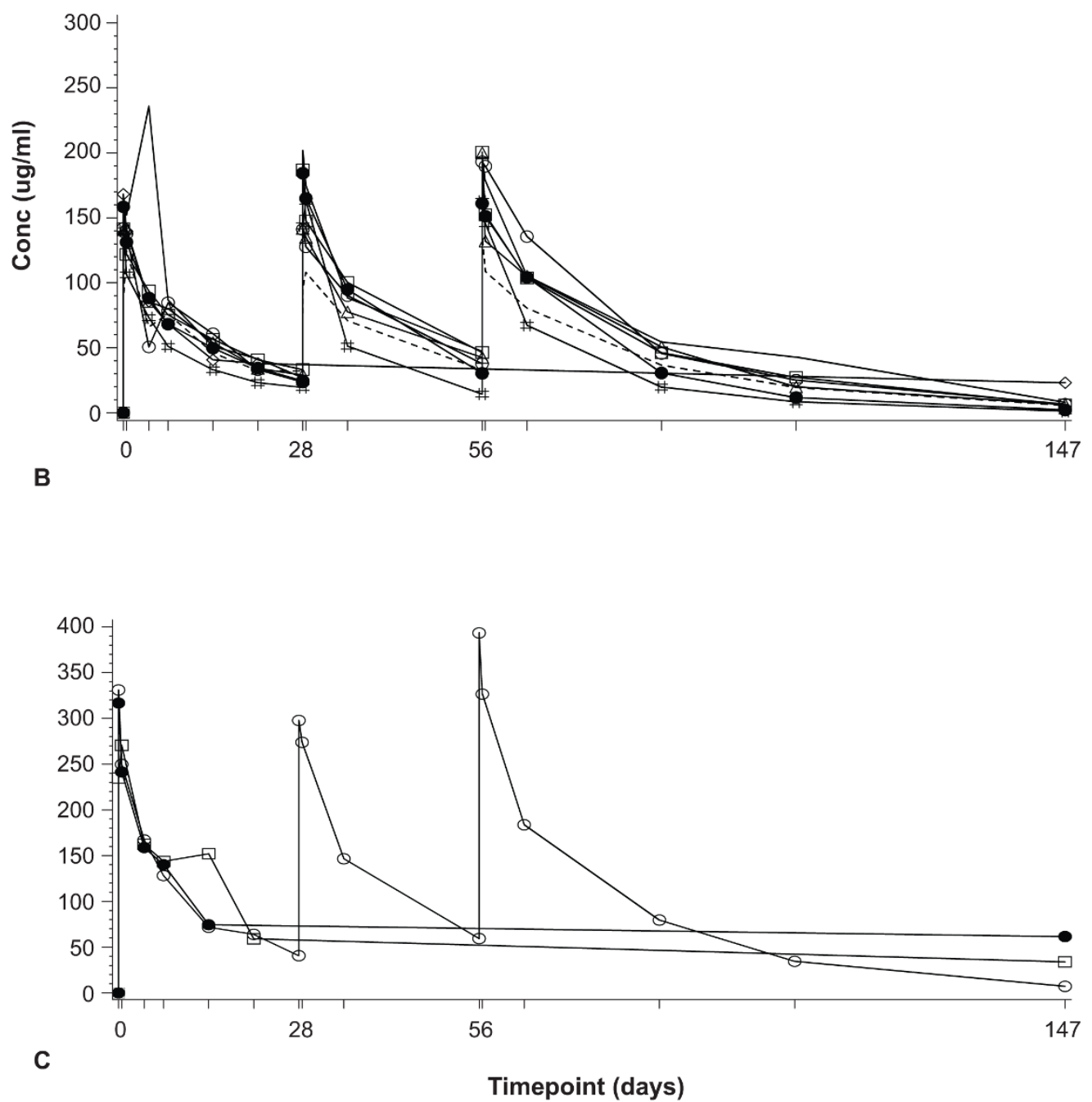

Figure 3 Serum concentration versus time profile of multiple doses of CAT-354 at doses of (A) $1 \mathrm{mg} / \mathrm{kg}$, (B) $5 \mathrm{mg} / \mathrm{kg}$ and (C) $10 \mathrm{mg} /$ $\mathbf{k g}$ administered at 28-day intervals by intravenous infusion. 
Table 2 Pharmacokinetic parameters after a single dose of CAT-354 (PK population)

\begin{tabular}{lccc}
\hline & \multicolumn{3}{c}{ CAT-354 } \\
\hline & $\begin{array}{c}1 \mathrm{mg} / \mathrm{kg} \\
(\mathrm{n}=8)\end{array}$ & $\begin{array}{c}5 \mathrm{mg} / \mathrm{kg} \\
(\mathrm{n}=8)\end{array}$ & $\begin{array}{c}10 \mathrm{mg} / \mathrm{kg} \\
(\mathrm{n}=3)\end{array}$ \\
\hline $\mathrm{C}_{\max }(\mu \mathrm{g} / \mathrm{mL})$ & $30.3(5.2)$ & $157(34.5)$ & $306(31.4)$ \\
$\mathrm{AUC}(0-\mathrm{t})(\mu \mathrm{g}$. day $/ \mathrm{mL})$ & $300(42.0)$ & $1691(303)$ & $3106(719)$ \\
$\mathrm{AUC}(0-\mathrm{inf})(\mu \mathrm{g}$. day $/ \mathrm{mL})$ & $428(83.3)$ & $2314(393)$ & $3861(662)$ \\
$\mathrm{t}_{1 / 2}($ days $)$ & $16.6(2.7)$ & $16.1(3.6)$ & $11.8(1.9)$ \\
$\mathrm{CL}^{*}(\mathrm{~mL} /$ day/kg) & $2.41(0.5)$ & $2.23(0.5)$ & $2.64(0.4)$ \\
$\mathrm{Vd}(\mathrm{mL} / \mathrm{kg})$ & $56.7(8.0)$ & $51.0(10.4)$ & $44.0(0.8)$ \\
\hline
\end{tabular}

Note: Values are arithmetic mean (SD) after dose 1.

${ }^{*}$ Corrected for body weight

Although assessment of the $10-\mathrm{mg} / \mathrm{kg}$ group was difficult due to the small sample size, the pharmacokinetics appeared to be proportional to those of lower doses (Table 2). Clearance (CL) $(2.2-2.6 \mathrm{~mL} / \mathrm{day} / \mathrm{kg})$ and volume of distribution (Vd) $(44-57 \mathrm{~mL} / \mathrm{kg})$ were both low and independent of dose level. The half-life after the third dose was 14.8-25.1 days.

$\mathrm{C}_{\max }$ and the concentration after 28 days $\left(\mathrm{C}_{28}\right)$ showed a small increase with multiple dosing (Table 3). These small increases were consistent with the calculated accumulation ratio $\left(R_{0}\right)$ for $A U C_{(0-t)}$. The mean $R_{0}$ was 1.58 , 1.39 and 1.67 for 1,5 and $10 \mathrm{mg} / \mathrm{kg}$ of CAT-354, respectively.

\section{Safety Profile}

All 23 subjects experienced at least 1 adverse event. The majority of adverse events were of mild or moderate intensity and were not considered treatment-related (70 unrelated adverse events). The most common events were nasopharyngitis (reported by 17 subjects) and headache (reported by 10 subjects) and were reported both in subjects receiving CAT-354 and those receiving placebo (Table 4).

Adverse events that were considered by the investigator to be possibly related to treatment with CAT-354

Table 3 Observed maximum concentration $\left(C_{\max }\right)$ and concentration after 28 days $\left(C_{28}\right)$ following three doses of CAT-354 (PK population)

\begin{tabular}{|c|c|c|c|}
\hline & \multicolumn{3}{|c|}{ CAT-354 } \\
\hline & $1 \mathrm{mg} / \mathrm{kg}$ & $5 \mathrm{mg} / \mathrm{kg}$ & $10 \mathrm{mg} / \mathrm{kg}$ \\
\hline \multicolumn{4}{|c|}{$C_{\max }(\mu \mathrm{g} / \mathrm{mL})$} \\
\hline Dose 1 & $30.3(5.2)[n=8]$ & $157(34.5)[\mathrm{n}=8]$ & $306(31.4)[n=3]$ \\
\hline Dose 2 & $35.0(6.8)[n=7]$ & $161(32.8)[n=7]$ & $298(-)[n=1]$ \\
\hline Dose 3 & $41.1(4.8)[n=6]$ & $179(25.4)[\mathrm{n}=7]$ & $393(-)[n=1]$ \\
\hline \multicolumn{4}{|c|}{$C_{28}(\mu \mathrm{g} / \mathrm{mL})$} \\
\hline Dose 1 & $5.3(1.3)[n=8]$ & $27.1(4.9)[n=7]$ & $40.7(-)[n=1]$ \\
\hline Dose 2 & $7.7(1.6)[n=6]$ & $36.0(11.5)[n=7]$ & $59.4(-)[n=1]$ \\
\hline Dose 3 & $8.6(2.0)[n=6]$ & $40.6(12.3)[n=7]$ & $79.6(-)[n=1]$ \\
\hline
\end{tabular}

Note: Values are arithmetic mean (SD).
Table 4 Incidence of most common adverse events (safety population)

\begin{tabular}{|c|c|c|c|c|}
\hline & \multicolumn{4}{|c|}{ No. (\%) of Subjects [No. of Events] } \\
\hline & \multicolumn{3}{|c|}{ CAT-354 } & \multirow[b]{2}{*}{$\begin{array}{c}\text { Placebo } \\
(n=4)\end{array}$} \\
\hline & $\begin{array}{c}1 \mathrm{mg} / \mathrm{kg} \\
(\mathrm{n}=8)\end{array}$ & $\begin{array}{c}5 \mathrm{mg} / \mathrm{kg} \\
(\mathrm{n}=8)\end{array}$ & $\begin{array}{c}10 \mathrm{mg} / \mathrm{kg} \\
(\mathrm{n}=3)\end{array}$ & \\
\hline Nasopharyngitis & $5(62.5)[6]$ & $\begin{array}{c}7(87.5) \\
{[10]}\end{array}$ & $2(66.7)[2]$ & $3(75.0)[4]$ \\
\hline Headache & $3(37.5)[3]$ & $4(50.0)[6]$ & $1(33.3)[1]$ & $2(50.0)[4]$ \\
\hline $\begin{array}{l}\text { Lower respiratory } \\
\text { tract infection }\end{array}$ & $1(12.5)[1]$ & $1(12.5)[1]$ & 0 & $1(25.0)[2]$ \\
\hline Cough & $1(12.5)[1]$ & $1(12.5)[1]$ & 0 & $1(25.0)[1]$ \\
\hline $\begin{array}{l}\text { Pharyngolaryngeal } \\
\text { pain }\end{array}$ & 0 & $1(12.5)[1]$ & $1(33.3)[2]$ & 0 \\
\hline Pain & $1(12.5)[1]$ & $1(12.5)[1]$ & 0 & 0 \\
\hline Chest discomfort & 0 & 0 & $1(33.3)[1]$ & $1(25.0)[1]$ \\
\hline Diarrhoea & $1(12.5)[1]$ & $1(12.5)[1]$ & 0 & 0 \\
\hline
\end{tabular}

were reported by three subjects. One subject experienced mild eczema that started 4 days after the second dose $(1 \mathrm{mg} / \mathrm{kg})$ and recovered after 6 weeks; 1 subject had a bloated stomach, epigastric discomfort and diarrhoea of moderate intensity on the day of the second dose $(5 \mathrm{mg} / \mathrm{kg})$ that lasted 2 days, plus moderate pain in the infusion arm that recovered on the same day; 1 subject experienced mild chest tightness on the day of dose $1(10 \mathrm{mg} / \mathrm{kg})$ that resolved on the same day.

Seven subjects were withdrawn from the study (Figure 2 ). One of these subjects was withdrawn after a chest infection that led to an exacerbation of asthma and was considered a serious adverse event. This occurred 20 days after the first dose $(5 \mathrm{mg} / \mathrm{kg})$ and was judged as unlikely to be related to the study drug. The subject recovered without obvious sequelae. Four additional subjects were withdrawn because of adverse events assessed by the investigator as unrelated or unlikely related to the study drug; 3 of these adverse events were respiratory tract infections. Two of these subjects received $1 \mathrm{mg} / \mathrm{kg}$, 1 subject received $10 \mathrm{mg} / \mathrm{kg}$ and 1 subject received placebo. Two other subjects withdrew; one was withdrawn by the investigator because of the need for treatment of a pre-existing condition, and the other subject withdrew due to inability to complete the visit schedule.

There were no clinically significant effects for vital signs, ECG, laboratory or physical examination parameters. There was no evidence of dose-related changes in $\mathrm{FEV}_{1}, \mathrm{FVC}, \mathrm{FEV}_{1} / \mathrm{FVC}$ ratio, and \% predicted $\mathrm{FEV}_{1}$ of clinical concern and no increased use of rescue SABA except for the subject who had an exacerbation of asthma.

\section{Immunogenicity}

There was no evidence of immunogenicity induced by CAT-354 in any of the samples collected from the subjects enrolled in this study. 


\section{Discussion}

This study has evaluated the pharmacokinetics and safety of CAT-354 at three dose levels administered by intravenous infusion on three occasions at intervals of 28 days. The pharmacokinetics were linear over the dose range studied. The half-life was found to be approximately 2-3 weeks, and the accumulation of drug was low. CAT-354 exhibited an acceptable safety profile with few adverse events that could have been related to treatment.

$\mathrm{C}_{\max }$ and AUC demonstrated a good relationship with dose level, whilst clearance and volume of distribution were independent of dose level, consistent with linear pharmacokinetics. The low clearance of CAT-354 (2.2$2.6 \mathrm{~mL} / \mathrm{day} / \mathrm{kg}$ ) was consistent with the expected clearance of an IgG antibody that is not subject to targetmediated disposition [17]. The observed maximum concentration $\left(\mathrm{C}_{\max }\right)$ after each dose and 28 days after each dose $\left(\mathrm{C}_{28}\right)$ increased by small amounts from dose 1 through dose 2 to dose 3 at all dose levels. The accumulation potential for CAT-354 was low with $R_{0}$ not much greater than 1 . However, with the observed pharmacokinetic characteristics, including low clearance, the drug remained at measurable concentrations in the serum, with levels still well above the quantifiable limit when final samples were taken up to 91 days after the final dose. The long half-life and low clearance of CAT-354 should maintain exposure to drug over the monthly dosing interval.

CAT-354 demonstrated an acceptable safety profile, with the majority of adverse events reported not related to study drug, and most events were of mild to moderate intensity. There were no dose-related adverse events and no subject experienced a serious adverse event that was thought to be related to study drug administration. There were two cases of diarrhoea post-infusion. Diarrhoea has been described as part of a constellation of symptoms that can occur during infusion reactions of mild intensity secondary to intravenous administration of antibodies [18]. These kinds of reactions, however, occurred at the lower doses of CAT-354, diminishing the likelihood of protein overload as a cause of the diarrhoea.

Seven subjects withdrew from the study, of which 5 were due to adverse events. Four of these adverse events were chest infections, with 3 occurring in the active treatment groups and 1 in the placebo group. It is to be expected that chest infections will occur in a multipledose study of long duration, and reassuringly there was no clear pattern for an increase in infections in the active treatment arms. The overall numbers of infections was low, and larger studies are needed to confirm the safety characteristics of this immune-modulating treatment. In addition, there were no effects of concern in any vital signs, ECG or laboratory parameters, and there were no effects of CAT-354 on lung function, which remained stable throughout the study treatment. There was no evidence of immunogenicity induced by CAT-354 in any of the samples collected during the study. These observations indicate that the doses of CAT-354 administered in the current study exhibited a safety profile suitable for further study. Future studies may also focus on the development of subcutaneous administration, as this will have practical advantages for administration.

There have been concerns about potential side effects of biological approaches to immunomodulation, such as the use of human monoclonal antibodies. The adverse event data, lung function, laboratory evaluations and immunogenicity tests in the current study suggest that CAT-354 can be safely administered in a repeat dosing schedule at doses up to $10 \mathrm{mg} / \mathrm{kg}$. Although only 3 subjects received the $10-\mathrm{mg} / \mathrm{kg}$ repeat dose, no additional safety concerns were identified at this dose compared to the lower doses. Future studies could test repeated doses up to $10 \mathrm{mg} / \mathrm{kg}$, and the next step for this drug would be to assess clinical efficacy such as through a properly powered study to evaluate pulmonary function. The current study used pulmonary function as a safety measure and was not properly powered to assess clinical benefits due to the low number of subjects.

The current study provides a safety assessment of multiple-dose administration of CAT-354 that supports further trials, and now efficacy studies are needed to evaluate the therapeutic potential of this drug. Pitrakinra is a recombinant IL-4 variant that competitively antagonises the IL-4R $\alpha$, and therefore interferes with the function of both IL- 4 and IL- 13 at the IL-4R $\alpha /$ IL-13R $\alpha 1$ receptor complex. This drug has been shown to inhibit the allergen challenge response in asthma [19]. The relative contributions of blocking IL-13 as opposed to IL-4 function to these results is not known, although animal studies suggest that IL-13 plays a dominant role in TH2 inflammation [10-14]. Human proof-of-concept studies using CAT-354 are required to confirm these animal findings.

\section{Conclusions}

The pharmacokinetics following repeat doses of 1 and 5 $\mathrm{mg} / \mathrm{kg}$ CAT-354 were characterised in this study. The $10-\mathrm{mg} / \mathrm{kg}$ treatment group, although of a small sample size, indicated pharmacokinetics that were broadly proportional to lower doses. The safety profile of CAT-354 observed in this study warrants the conduct of future studies to evaluate clinical efficacy. 


\section{Acknowledgements}

The authors would like to thank Adrian Quartel, Chiltern International Limited, and Diana Jones for help in the preparation of this manuscript, sponsored by Medlmmune, LLC.

\section{Author details}

'Medicines Evaluation Unit, University Hospital of South Mancheste Foundation Trust, University of Manchester, Manchester, UK. ${ }^{2}$ Respiratory and Inflammation, Medlmmune LLC, Gaithersburg, Maryland, USA.

\section{Authors' contributions}

DS, BK and AW were investigators for this study. RF and LR performed the pharmacokinetic analyses. NM participated in the design and coordination of this study. All authors read and approved the final manuscript.

\section{Competing interests}

The authors NAM, RF and LR are employees of Medlmmune, LLC.

Received: 6 May 2009

Accepted: 8 January 2010 Published: 8 January 2010

\section{References}

1. Global strategy for asthma management and prevention. 2007http:// www.ginasthma.com, Last updated.

2. Partridge MR, van der Molen T, Myrseth SE, Busse WW: Attitudes and actions of asthma patients on regular maintenance therapy: the INSPIRE study. BMC Pulm Med 2006, 13:6-13.

3. Bateman ED, Boushey HA, Bousquet J, Busse WW, Clark TJ, Pauwels RA, Pedersen SE, GOAL Investigators Group: Can guideline defined asthma control be achieved? The Gaining Optimal Asthma Control study. Am J Respir Crit Care Med 2004, 170:836-844.

4. Robinson DS, Hamid Q, Ying S, Tsicopoulos A, Barkans J, Bentley AM, Corrigan C, Durham SR, Kay AB: Predominant TH2-like bronchoalveolar Tlymphocyte population in atopic asthma. N Engl J Med 1992, 326:298-304.

5. Hogan SP, Mould AW, Young JM, Rothenberg ME, Ramsay AJ, Matthaei K, Young IG, Foster PS: Cellular and molecular regulation of eosinophil trafficking to the lung. Immunol Cell Biol 1998, 76:454-460.

6. Brightling CE, Symon FA, Birring SS, Bradding P, Pavord ID, Wardlaw AJ: TH2 cytokine expression in bronchoalveolar lavage fluid T lymphocytes and bronchial submucosa is a feature of asthma and eosinophilic bronchitis. J Allergy Clin Immunol 2002, 110:899-905.

7. Berry MA, Parker D, Neale N, Woodman L, Morgan A, Monk P, Bradding P, Wardlaw AJ, Pavord ID, Brightling CE: Sputum and bronchial submucosal IL-13 expression in asthma and eosinophilic bronchitis. J Allergy Clin Immunol 2004, 114:1106-1109.

8. Saha SK, Berry MA, Parker D, Siddiqui S, Morgan A, May R, Monk P, Bradding P, Wardlaw AJ, Pavord ID, Brightling CE: Increased sputum and bronchial biopsy IL-13 expression in severe asthma. J Allergy Clin Immunol 2008, 121:685-691.

9. Brightling CE, Symon FA, Holgate ST, Wardlaw AJ, Pavord ID, Bradding P: Interleukin-4 and -13 expression is co-localized to mast cells within the airway smooth muscle in asthma. Clin Exp Allergy 2003, 33:1711-1716.

10. Zhu Z, Homer RJ, Wang Z, Chen Q, Geba GP, Wang J, Zhang Y, Elias JA: Pulmonary expression of interleukin-13 causes inflammation, mucus hypersecretion, subepithelial fibrosis, physiologic abnormalities, and eotaxin production. J Clin Invest 1999, 103:779-788.

11. Pope SM, Brandt EB, Mishra A, Hogan SP, Zimmermann N, Matthaei KI Foster PS, Rothenberg ME: Interleukin-13 induces eosinophil recruitment to the lung by an IL-5 and eotaxin dependent mechanism. J Allergy Clin Immunol 2001, 108:594-601.

12. Grunig G, Warnock M, Wakil AE, Venkayya R, Brombacher F, Rennick DM, Sheppard D, Mohrs M, Donaldson DD, Locksley RM, Corry DB: Requirement for IL-13 independently of IL-4 in experimental asthma. Science 1998, 282:2261-2263

13. Wills-Karp M, Luyimbazi J, Xu X, Schofield B, Neben TY, Karp CL, Donaldson DD: Interleukin-13: central mediator of allergic asthma. Science 1999, 282:2258-2261.

14. Mattes J, Yang M, Mahalingam S, Kuehr J, Webb DC, Simson L, Hogan SP, Koskinen A, McKenzie AN, Dent LA, Rothenberg ME, Matthaei KI, Young IG Foster PS: Intrinsic defect in T cell production of interleukin (IL)-13 in the absence of both IL-5 and eotaxin precludes the development of eosinophilia and airways hyperreactivity in experimental asthma. J Exp Med 2002, 195:1433-1444.

15. Mire-Sluis AR, Barrett YC, Devanarayan V, Koren E, Liu H, Maia M, Parish T, Scott G, Shankar G, Shores E, Swanson SJ, Taniguchi G, Wierda D, Zuckerman LA: Recommendations for the design and optimization of immunoassays used in the detection of host antibodies against biotechnology products. J Immunol Methods 2004, 289:1-16.

16. Food and Drug Administration (FDA), Center for Drug Evaluation Research (CDER), Center for Biologics Evaluation and Research (CBER): General considerations for pediatric pharmacokinetic studies for drugs and biological products. Draft Guidance for Industry 1998http://www.fda.gov/ downloads/Drugs/GuidanceComplianceRegulatoryInformation/Guidances/ ucm072114.pdf.

17. Tabrizi MA, Roskos LK: Preclinical and clinical safety of monoclonal antibodies. Drug Discov Today 2007, 12:540-547.

18. Cheifetz A, Mayer L: Monoclonal antibodies, immunogenicity and associated infusion reactions. Mount Sinai J Med 2005, 72:250-256.

19. Wenzel S, Wilbraham d, Fuller R, Getz EB, Longphre M: Effect of an interleukin-4 variant on late phase asthmatic response to allergen challenge in asthmatic patients: results of two phase 2a studies. Lancet 2007, 370:1422-31.

\section{Pre-publication history}

The pre-publication history for this paper can be accessed here:http://www biomedcentral.com/1471-2466/10/3/prepub

doi:10.1186/1471-2466-10-3

Cite this article as: Singh et al: A phase 1 study evaluating the pharmacokinetics, safety and tolerability of repeat dosing with a human IL-13 antibody (CAT-354) in subjects with asthma. BMC Pulmonary Medicine 2010 10:3.

\section{Publish with Biomed Central and every scientist can read your work free of charge}

"BioMed Central will be the most significant development for disseminating the results of biomedical research in our lifetime. "

Sir Paul Nurse, Cancer Research UK

Your research papers will be:

- available free of charge to the entire biomedical community

- peer reviewed and published immediately upon acceptance

- cited in PubMed and archived on PubMed Central

- yours - you keep the copyright
BioMedcentral 